\title{
Balancing power relations for food security
}

\author{
Book review by Molly D. Anderson * \\ Middlebury College
}

Review of Food Security Governance: Empowering Communities, Regulating Corporations, by Nora McKeon.

(2015). Published by Routledge. Available as hardcover, paperback, and eBook; 246 pages. Publisher's website: http://www.routledge.com/books/details/9780415529105

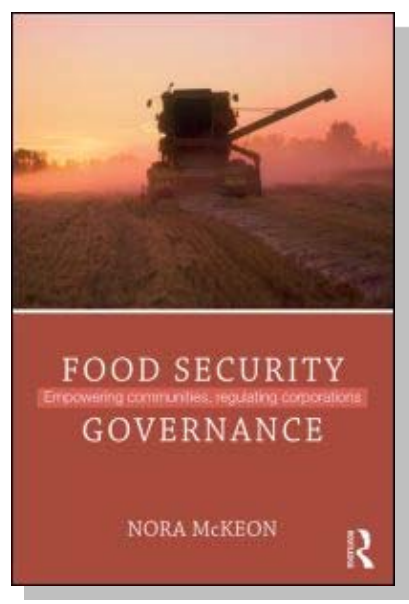

Submitted April 8, 2015 / Published online December 10, 2015

Citation: Anderson, M. D. (2015). Balancing power relations for food security [Book review]. Journal of Agriculture, Food Systems, and Community Development, 6(1), 213-214. http://dx.doi.org/10.5304/jafscd.2015.061.017

Copyright (C) 2015 by New Leaf Associates, Inc.

$\mathrm{O}$ pinions about how to better govern food systems to prevent food shortages and food price jumps have diverged since the food crisis of 2007-2008, with battle lines drawn between camps that have little common ground other than the shared understanding that hunger is a huge yet ultimately tractable problem. On one side are interests claiming that increased production is essential; on the other side are those who say increased control by hungry people of access to resources and

* Molly D. Anderson, William R. Kenan Professor of Food Studies, Middlebury College; 119 Franklin Environmental Center on Hillcrest; Middlebury, Vermont 05753 USA; +1-802-443-3644; MollyA@middlebury.edu

Molly D. Anderson teaches about food security, food sovereignty, and sustainable food systems at Middlebury College, where she is also developing a Food Studies Program. She is a member of the International Panel of Experts on Sustainable Food Systems, and has written extensively on how the food system can be improved to attain the right to food and greater sustainability. markets are much more important, and increasing production will do little to solve hunger without concomitant sociopolitical changes.

One of the consequences of the global failure to predict and protect vulnerable people from food price jumps was the reform of the United Nations Committee on World Food Security (CFS) in 2009. Understanding the CFS and the Food and Agriculture Organization of the United Nations (FAO), which hosts the CFS's annual meetings, is critical to understanding how decisions are playing out that affect whether millions of people have sufficient healthy food to eat, as well as control over how that food is produced, by whom, and for whose benefit.

Imagine a knowledgeable guide to the CFS who accompanies you through the halls of the FAO — playing Virgil to your Dante — while explaining the background, history, and important actors who have shaped current issues. Nora McKeon is just such a guide: she brings an 
unparalleled perspective on the CFS, having worked as civil society liaison for the FAO for years and now regularly engaging in Rome with CFS activities and in Africa with grassroots food sovereignty activists. Food Security Governance: Empowering Communities, Regulating Corporations picks up the story and questions she introduced in her previous book, The United Nations and Civil Society: Legitimating Global Governance - Whose Voice? (Zed Books, 2009).

This book begins with a historical review of food governance and its intersection with the rise of neoliberalism. Next, various perspectives and approaches to food provision are described, with the corporate-led global food system contrasted with small-scale family farming and the local food webs that feed most of the world's people today. Productivism is counterpoised with food sovereignty and the right to food. The story moves into the recent reform of the CFS after its failure to predict or resolve the precipitous rise in food prices in 2007-2008 that pushed hundreds of thousands of people over the brink into food insecurity. The reform was designed to overcome policy fragmentation; be more inclusive of people most affected by hunger through the creation of a Civil Society Mechanism; use the right to food as a foundation for all policies; and move past ideological paradigms through evidence-based reports provided by a High Level Panel of Experts. The next chapters describe the efforts of food sovereignty movements to build a better food system from the bottom up, meeting the efforts at the global level to institutionalize those improvements from the top down, with particular attention to deliberations on tenure guidelines and agricultural investments. The book ends with a strong message of hope that food governance can escape the single-minded emphasis on profit for the few dominant capitalist interests and move to being accountable for achieving human rights for the people who are not served at present: hungry people and the small-scale producers whose livelihoods are being destroyed by corporate-controlled industrialized agriculture. Such accountability would bring powerful environmental and health benefits, as well as greater equity and justice. The CFS may be somewhere in Purgatory now; we cannot yet know whether the 2009 reform will lead to full accountability of governments to their people. But McKeon believes that it is on the right track and shows great potential.

This book is clearly organized and written in accessible, compelling language. There is abundant documentation of factual material and good interconnections between chapters. With each topic she raises, McKeon avoids superficial explanations and digs deeply into the motivations, obstacles, and successes of the actors involved. Her sympathies for social movement actors are clear, but this does not blur a sharply etched portrayal of the challenges that civil society has met in the six years since the CFS reform.

While food security governance may seem at first glance to be a rather dry subject, this book illustrates its importance to the present-day and future well-being of most people in the world. In the United States, interest in food justice has risen rapidly over the past decade. Food governance and democracy are perhaps the most critical elements of food justice, although they are just beginning to emerge as emphases in the U.S. Justice will not be possible without the full political participation of marginalized people affected by food policies. This book is an excellent addition to upper-level undergraduate or graduate courses on food security, food justice, and the sociopolitical context of food. In addition, it will be useful to policy-makers who want to understand the global context of efforts to address food security. 